\title{
PERHITUNGAN KAPASITAS DUKUNG FONDASI TIANG TUNGGAL MENGGUNAKAN CLUSTERING DATA STANDARD PENETRATION TEST (SPT)
}

\author{
Raden Harya Dananjaya1); Noegroho Djarwanti2); Hida Alifa Rahma ${ }^{3)}$ \\ 1),2) Dosen Pembimbing Skripsi \\ 3) Mahasiswa Teknik Sipil \\ Jalan Ir. Sutami Nomor 36A Kentingan Surakarta 57126 \\ Telepon (0271) 647069 Psw. 120,121, 08112633314 , Fax. (0271) 634524 \\ Email : alifarahma@student.uns.ac.id
}

\begin{abstract}
Soil investigation is one of the essential things in construction planning. It is needed for selecting the foundation type that will be used. One of the types of soil investigation is the Standard Penetration Test (SPT). It is only done in a few points only when doing construction for a building because high cost. This research will explain the development of the calculation method of the foundation bearing capacity by optimizing the use of secondary data so that the foundation bearing capacity in the other points where soil investigation is not being carried out can be predicted. Clustering method of categorizing types of land based air-value prisoners $N_{\text {rata-rata. }}$ Plotting $N_{\text {rata-rata }}$ value into QGIS to do clustering soil types. Prediction capacity of a single pile foundation support $\left(Q_{u}\right)$ on the inner pillars based on data used confidence interval. Confedence intervals predict the value of $Q_{u}$ and the depths of the unknownvalue.

The results of the analysis of the QGIS the cluster has two types of soil silt and clay soil i.e. soil clays. The greater the confidence levelyielding capacity of support the foundation pillar of single stake $\left(Q_{n}\right)$ is getting smaller. If taken $30 \mathrm{~cm}$ depth of 8 meters in diameter cluster solid clay, then the results of the reading graph shows the value of $Q_{n}$ a $60 \%$ confidence level $961,42 \mathrm{kN}, 80 \%=858,60 \mathrm{kN}$, dan 95\% $=719,19 \mathrm{kN}$. The increasinglydense layers of soil required capacity support ultimit. This is shown by the value of $Q_{u}$ cluster silt clays is smaller than the dense clays cluster if taken diameter $50 \mathrm{~cm}$ and a depth of $10 \mathrm{~m}$ with a $60 \%$ confidence level is obtained a value of $Q_{n}$ of $1663 \mathrm{kN}$ on silt and clays cluster value of $Q_{n}$ of $3716 \mathrm{kN}$ on a cluster of solid clay.
\end{abstract}

Keywords: single pile foundations, clustering, SPT, QGIS

\begin{abstract}
Abstrak
Penyelidikan tanah merupakan salah satu proses penting dalam perencanaan pembangunan. Penyelidikan tanah dibutuhkan untuk menentukan jenis fondasi yang akan digunakan. Salah satu penyelidikan tanah adalah uji Standard Penetration Test (SPT). Penelitian ini akan memaparkan pengembangan metode perhitungan kapasitas daya dukung fondasi dengan mengoptimalkan penggunaan data sekunder, sehingga dapat memprediksi kapasitas daya dukung di titik lain yang tidak dilakukan pengujian tanah. Metode clustering mengelompokkan jenis tanah berdasarkan nilai $\mathrm{N}_{\text {rata-rata }}$ data SPT. Nilai $\mathrm{N}_{\text {rata-rata }}$ diplotkan kedalam QGIS untuk dilakukan clustering jenis tanah. Prediksi kapasitas dukung fondasi tiang tunggal $\left(\mathrm{Q}_{\mathrm{u}}\right)$ pada kedalaman tiang berdasarkan data SPT digunakan interval kepercayaan. Interval kepercayaan memprediksi nilai $\mathrm{Q}_{\mathrm{u}}$ dan kedalaman yang belum diketahui nilainya. Nilai $\mathrm{Q}_{\mathrm{u}}$ setiap kedalaman $(\mathrm{z})$ yang dihitung dengan tingkat kepercayaan kemudian dihubungkan menggunakan grafik berdasarkan cluster. Hasil analisis QGIS memiliki dua cluster jenis tanah yaitu tanah lempung sangat kaku dan tanah lempung keras. Tingkat kepercayaan semakin besar menghasilkan kapasitas dukung fondasi tiang pancang tunggal $\left(\mathrm{Q}_{\mathrm{u}}\right)$ semakin kecil. Jika diambil diameter $30 \mathrm{~cm}$ kedalaman 8 meter cluster lempung keras, maka hasil pembacaan grafik menunjukkan nilai $\mathrm{Q}_{\mathrm{u}}$ interval kepercayaan $60 \%=961,42 \mathrm{kN}, 80 \%=858,60 \mathrm{kN}$, dan $95 \%=719,19 \mathrm{kN}$. Lapisan tanah yang semakin keras diperlukan kapasitas dukung ultimit yang lebih besar. Hal ini ditunjukkan oleh nilai $\mathrm{Q}_{\mathrm{u}}$ cluster lempung sangat kaku lebih kecil daripada cluster lempung keras jika diambil diameter $50 \mathrm{~cm}$ dan kedalaman $10 \mathrm{~m}$ dengan interval kepercayaan 60\% diperoleh nilai $\mathrm{Q}_{\mathrm{u}}$ sebesar $1663 \mathrm{kN}$ pada cluster lempung sangat kaku dan nilai $\mathrm{Q}_{\mathrm{u}}$ sebesar $3716 \mathrm{kN}$ pada clusterlempung keras
\end{abstract}

Kata Kunci :fondasi tiang pancang tunggal, clustering, SPT, QGIS 


\section{PENDAHULUAN}

Penyelidikan tanah merupakan salah satu proses penting dalam perencanaan pembangunan. Penyelidikan tanah dibutuhkan untuk menentukan jenis fondasi yang akan digunakan. Salah satu penyelidikan tanah adalah uji Standard Penetration Test (SPT). Biaya yang digunakan dalam penyelidikan tanah cukup tinggi, maka dalam pembangunan suatu bangunan hanya di beberapa titik saja yang dilakukan. Jika penyelidikan tanah dilakukan langsung saat pembangunan maka hasil dari penyedilikan tanah tersebut menjadi data primer. Data primer bisa dijadikan sebagai data sekunder untuk penelitian atau pembangunan selanjutnya. Penggunaan data sekunder saat ini belum dimaanfaatkan dengan baik.

Penelitian ini akan memaparkan pengembangan metode perhitungan kapasitas daya dukung fondasi dengan mengoptimalkan penggunaan data sekunder, sehingga dapat memprediksi kapasitas daya dukung di titik lain yang tidak dilakukan pengujian tanah. Terlebih saat ini banyak pembangunan bangunan tinggi yang menggunakan jenis fondasi dalam. Dalam perencanaan fondasi dalam pengujian tanah sangat penting untuk menentukan letak tanah keras yang dapat dijadikan sebagai dasar fondasi, sehingga diperlukan banyak data untuk perencanaan fondasi yang akan digunakan. Metode untuk memprediksi kapasitas daya dukung fondasi ini nantinya dapat dijadikan alat untuk mendapatkan data tanpa perlu melakukan pengujian.

\section{Landasan Teori}

\section{Penyelidikan Tanah}

Penyelidikan tanah merupakan suatu kegiatan yang bertujuan untuk mengetahui sifat-sifat tanah dan karateristik tanah untuk keperluan rekayasa. Penyelidikan tanah umumnya digunakan sebagai dasar dalam merencanakan pondasi, untuk mengetahui susunan lapisan tanah pada lokasi perencanaan. Pengambilan sampel tanah ini dengan cara menge-bor sampai kedalaman tertentu dengan menggunakan tabung (pipa) logam berongga ke dalam tanah. Setelah didapatkan sampel tanah, sampel diuji di laboratorium namun hanya tanah pada lapisan kedalaman yang dibutuhkan sesuai rencana. Salah satu metode penyelidikan tanah yang hasilnya digunakan untuk penelitian yaitu Standard Penetration Test (SPT).

\section{Clustering}

Clustering merupakan suatu metode menganalisa data untuk mengelompokkan data dengan karakteristik yang sama ke wilayah yang sama dan data dengan karakteristik berbeda ke wilayah lain. Beberapa pendekatan yang digunakan dalam mengembangkan metode clustering yaitu pendekatan partisi dan hirarki. Clustering pendekatan partisi mengelompokkan data dengan memilah-milah data yang dianalisis ke dalam cluster-cluster yang ada. Clustering dengan pendekatan hirarki mengelompokkan data dengan membuat suatu hirarki dimana data yang mirip akan ditempatkan pada hirarki yang berdekatan. Pengelompokkan data berdasarkan pada kedekatan dari suatu karakteristik sampel yang ada, misalnya menurut klasifikasi.

Penelitian menggunakan clustering dengan pendekatan partisi untuk mengelompokkan data. Data yang dikelompokkan berupa rata-rata nilai $\mathrm{N}_{S P T}$ untuk dianalisis ke dalam cluster. Perhitungan $\mathbf{N}_{\text {rata-rata }}$ menggunakan aritmatik biasa seperti berikut:

$N_{\text {rata-rata }}=\frac{N_{0,5}+N_{1,0}+N_{1,5}+\ldots+N_{\mathrm{i}}}{n}$

Tabel 1. Hubungan N, $q_{c}$ dengan konsistensi untuk tanah lempung (Terzagbi and Peck, 1948)

\begin{tabular}{ccc}
\hline Konsistensi & $\mathrm{N}_{\text {SPT }}$ & $\mathrm{qc}(\mathrm{kg} / \mathrm{cm} 2)$ \\
\hline \hline Sangat lunak & $0-2$ & $0-8$ \\
\hline Lunak & $2-4$ & $8-16$ \\
\hline Sedang & $4-8$ & $16-32$ \\
\hline Kaku & $8-15$ & $32-60$ \\
\hline Sangat kaku & $15-30$ & $60-120$ \\
\hline Keras & $>30$ & $>120$ \\
\hline
\end{tabular}




\section{Interval Kepercayaan}

Salah satu ilmu statistika yang digunakan sebagai penduga parameter populasi berdasarkan sampel adalah interval kepercayaan atau confidence interval dimana ilmu ini menghasilkan dugaan parameter yang representatif terhadap parameternya dibanding dengan penduga titik. Interval kepercayaan merupakan suatu interval antara dua angka, dimana nilai parameter suatu populasi yang belum diketahui dipercaya terletak diantara interval tersebut. Idealnya selang dianggap terbaik dan mempunyai tingkat kepercayaan paling tinggi dalam mengestimasi suatu parameter adalah interval yang paling pendek dengan derajat kepercayaan tinggi. Banyak interval kepercayaan yang dapat dibentuk dalam suatu populasi adalah tak terhingga, penentuan derajat kepercayaan dan lebar intervalnya bebas. Interval kepercayaan lebih informatif daripada hipotesis sederhana hasil tes dimana diputuskan menolak atau menerima hipotesisi nol (H0) atau hipotesis yang diuji, karena interval kepercayaan telah menyediakan serangkaian nilai-nilai yang masuk akal untuk parameter yang tidak diketahui.

Interval kepercayaan memiliki derajat kepercayaan yang ditulis dengan $\alpha$. Derajat kepercayaan adalah besarnya kesalahan hasil dugaan yang dapat diterima atau ditolerir. Besarnya kesalahan disebut sebagai daerah kritis pengujian atau daerah penolakan. Interval kepercayaan untuk sampel data sebanyak lebih besar sama dengan 30 ditentukan menggunakan suatu nilai $z_{-}(\alpha / 2)$ untuk uji dua pihak dan z $\alpha$ untuk uji sepihak. Nilai z diperoleh dari tabel distribusi normal standar kritis. Interval kepercayaan untuk sampel data kurang dari 30 nilai $z$ berubah menjadi t dimana nilai t diperoleh dari tabel distribusi student's t.

\section{Fondasi Tiang Pancang Tunggal}

Tiang pancang adalah bagian-bagian konstruksi yang dibuat dari kayu, beton, dan atau baja, yang digunakan untuk meneruskan (mentransmisikan) beban-beban permukaan ke tingkat-tingkat permukaan yang lebih rendah di dalam massa tanah (Bowles, J. E., 1991).

Penggunaan fondasi tiang pancang sebagai fondasi bangunan apabila tanah yang berada dibawah dasar bangunan tidak mempunyai daya dukung yang cukup untuk memikul berat bangunan dan beban yang bekerja padanya (Sardjono, H. S., 1988). Atau apabila tanah yang mempunyai daya dukung yang cukup untuk memikul berat bangunan dan seluruh beban yang bekerja berada pada lapisan yang sangat dalam dari permukaan tanah kedalaman $>8 \mathrm{~m}$ (Bowles, J. E., 1991).

\section{Daya Dukung Tiang dari Data SPT}

Daya dukung tiang adalah kemampuan tiang dalam memikul beban yang disalurkan oleh struktur diatasnya dengan sejajar sumbu tiang (axial load). Dalam menentukan kapasitas dukung ujung tiang tergantung dari jenis tanahnya menurut cara Meyerhof (1976).

Persamanaan Metode Meyerhof (1976) untuk memperoleh kapasitas daya dukung ultimate, berikut:

$$
Q_{u}=Q_{b}+Q_{s}
$$

dengan:

$\mathrm{Q}_{\mathrm{u}}=$ Kapasitas daya dukung aksial ultimate tiang bor.

$\mathrm{Q}_{\mathrm{b}}=$ Kapasitas tahanan di titik (ujung) tiang.

$\mathrm{Q}_{\mathrm{s}}=$ Kapasitas tahanan gesek kulit.

Perkiraan kapasitas daya dukung pondasi tiang pancang pada tanah pasir dan silt didasarkan pada data uji lapangan SPT, ditentukan dengan perumusan sebagai berikut :

1. Kekuatan ujung tiang (end bearing), (Meyerhof, 1976).

Untuk tanah pasir dan kerikil :

$$
Q_{b}=40 . N_{\mathrm{SPT}} \cdot L_{i} / d . A p<400 . N_{\mathrm{SPT}} \cdot A_{\mathrm{P}}
$$

Untuk tahanan gesek kulit tiang adalah:

$$
Q s=2 N_{\mathrm{SPT}} \cdot p . L
$$

Kekuatan ujung tiang (end bearing) untuk tanah kohesif plastis :

$$
\begin{aligned}
& Q_{b}=\mathrm{q}_{\mathrm{p}} \cdot \mathrm{A}_{\mathrm{p}} \ldots \ldots \ldots \ldots . . . . . \\
& \mathrm{q}_{\mathrm{p}}=9 . C_{u} \ldots \ldots \ldots \ldots \ldots \\
& C_{u}=N_{S P T} \cdot \frac{2}{3} \cdot 10 .
\end{aligned}
$$

Untuk tahanan geser selimut tiang adalah:

$$
\begin{aligned}
& Q_{s}=f \cdot p \cdot L_{i} \\
& f=a . C_{u} \ldots \ldots .
\end{aligned}
$$




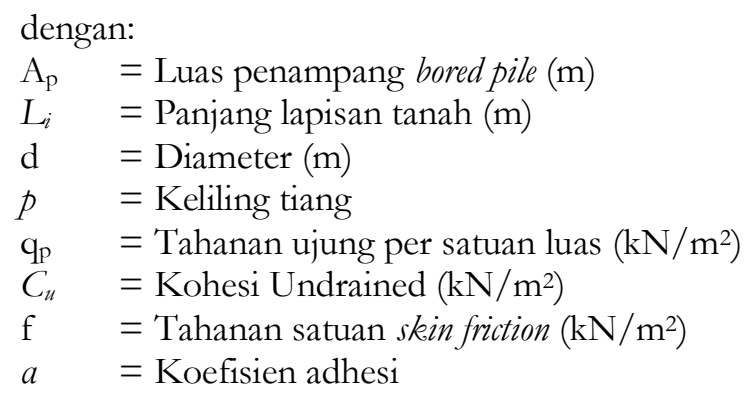

\section{Quantum Geographic Information System}

Quantum Geographic Information System (QGIS) merupakan suatu perangkat sistem informasi geografis dengan sumber terbuka atau tidak memerlukan lisensi. Gerry Sherman adalam pembangun pertama kali QGIS pada awal 2002, merelease versi 1.0 pada tahun 2009. QGIS menyediakan semua fungsionalitas dan fitur-fitur yang dibutuhkan pengguna SIG pada umumnya. Penggunaan plugins dan fitur-ini memungkinkan untuk membuat peta. Pengguna QGIS dapat menghubungkan data, menggabungkan, menganalisis dan memetakan, mengelola sesuai keinginan. Aplikasi QGIS dapat digunakan untuk menjawab pertanyaan lokasi, kondisi, pola, serta pemodelan. Selain itu, QGIS memiliki ukuran file kecil dan memerlukan RAM kecil sehingga dapat digunakan di berbagai jenis komputer.

Penggunaan QGIS pada penelitian ini untuk memudahkan pemetaan clustering kapasitas dukung fondasi tiang tunggal. QGIS akan menginterpolasi sebuah garis yang menghubungkan lokasi-lokasi dengan nilai $\mathrm{N}_{\text {rata-rata }}$ sesuai klasifikasi jenis tanah. Hasil interpolasi kemudian dibuat peta yang berfungsi untuk menunjukkan jenis tanah pada wilayah Kota Surakarta.

\section{METODE PENELITIAN}

\section{Lokasi Penelitian}

Lokasi penelitian ini di Kota Surakarta.

\section{Data Penelitian}

Data SPT

Data SPT merupakan data sekunder yang berasal dari arsip Laboratorium Mekanika Tanah Program Studi Teknik Sipil Fakultas Teknik Universitas Sebelas Maret.

\section{Data Spasial}

Data spasial berupa peta administrasi, jalan, drainasi, penutup lahan, dan kontur yang berasal dari peta digital rupa bumi Indonesia (RBI) wilayah Surakarta nomor 1408-343 skala 1:25.000.

Pengolahan Data

\section{HASIL DAN PEMBAHASAN \\ Pembuatan Peta}

Keseluruhan data yang dapat digunakan dalam perhitungan ini ada sebanyak 63 titik. Data uji SPT yang digunakan merupakan nilai jumlah pukulan yang dibutuhkan untuk penetrasi tabung belah standar yang kemudian didefinisikan sebagai $\mathrm{N}_{\text {SPT. }}$. $\mathrm{N}_{\text {SPT }}$ dihitung rata-rata aritmatiknya, nilai rata-rata dianggap mewakili nilai $\mathrm{N}_{\text {SPT }}$ pada setiap titik pengujian.

Cluster jenis tanah ditentukan berdasarkan $N_{\text {rata-rata }}$ merujuk pada klasifikasi jenis tanah berdasarkan $N_{\text {rata-rata }}$ oleh Terzaghi dan Peck (1948). Hasil perhitungan $N_{\text {rata-rata }} 63$ titik sondir, diperoleh data SPT yang digunakan pada penelitian ini termasuk kedalam dua klasifikasi jenis tanah yaitu tanah lempung sangat kaku (LSK) dan lempung keras (LR). Klasifikasi jenis tanah lempung sangat kaku dengan nilai $N_{\text {rata-rata }}$ berada diantara 15-30 sedangkan 45 titik SPT termasuk klasifikasi jenis tanah lempung keras dengan $N_{\text {rata- }}$ rata berada dilebih dari 30 . 


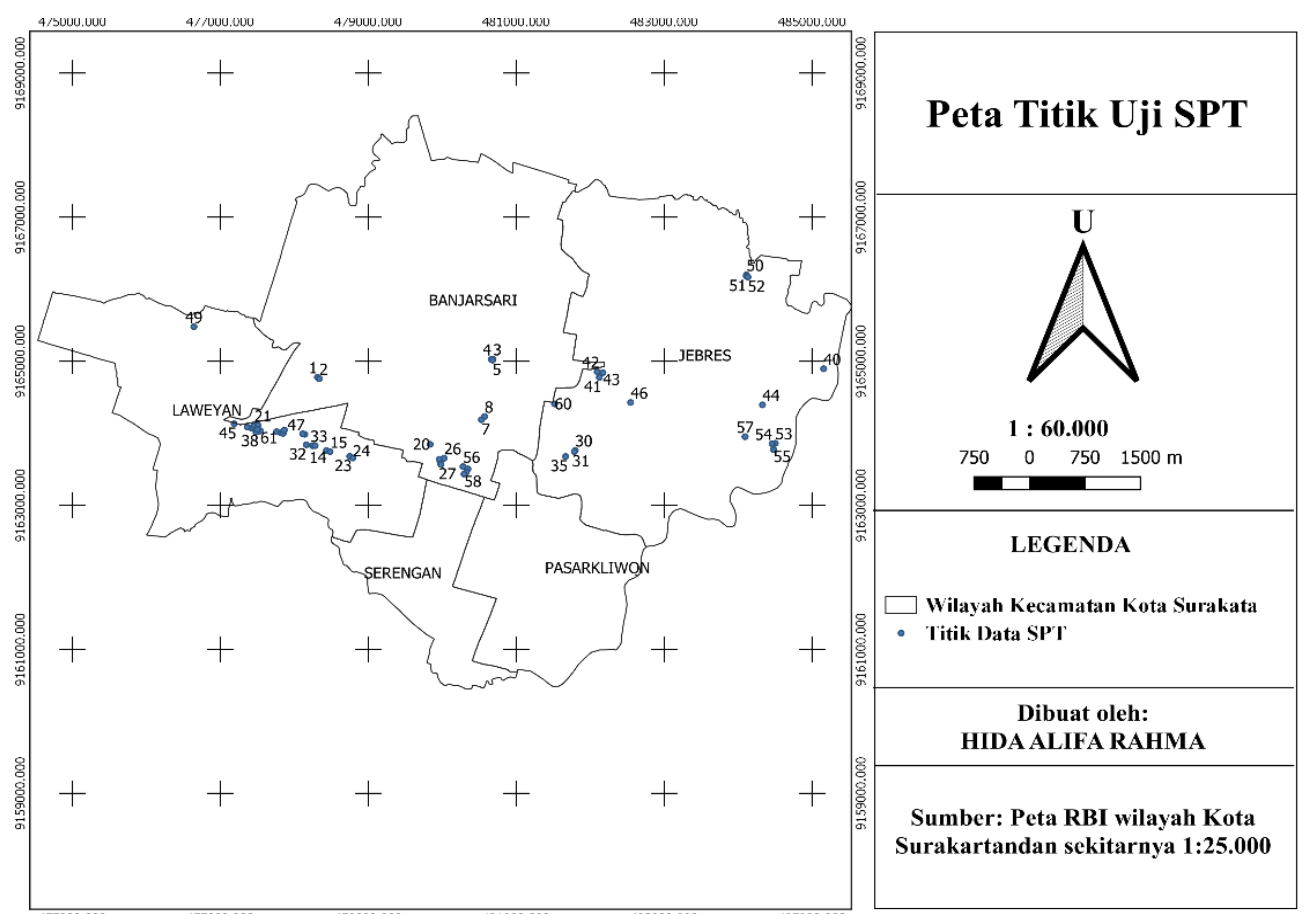

Gambar 1. Hasil plotting $N_{\text {rata-rata }}$ dan koordinat lokasi setiap titik

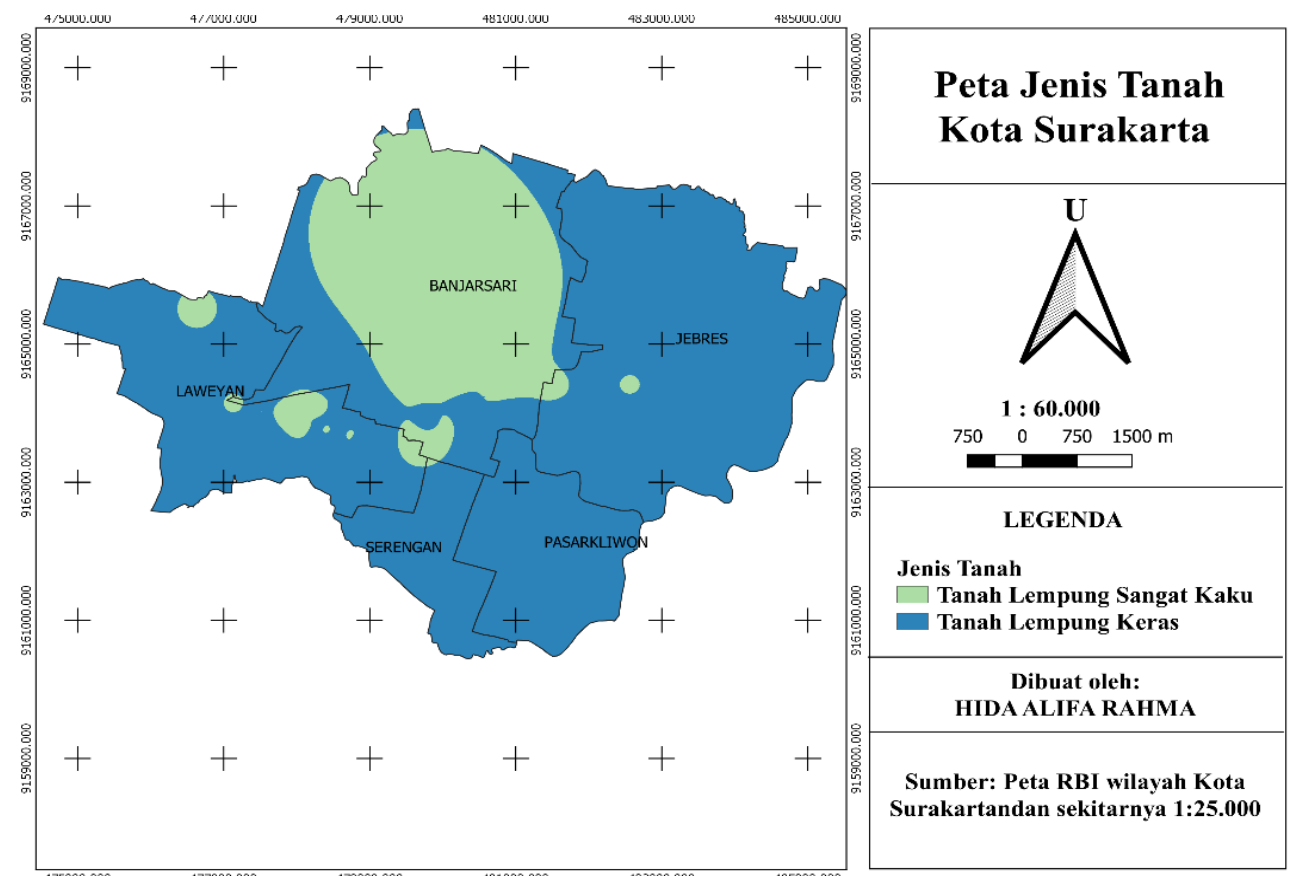

Gambar 2. Hasil interpolasi $\mathrm{N}_{\text {rata-rata }}$

Pembuatan Grafik Hubungan Kapasitas Dukung Ultimit Fondasi Tiang Pancang Tunggal $\left(\mathrm{Q}_{\mathrm{u}}\right)$ dengan Kedalaman (z)

Proses pembuatan grafik hubungan kapasitas dukung fondasi tiang tunggal $\left(\mathrm{Q}_{\mathrm{u}}\right)$ dengan kedalaman $(\mathrm{z})$ dilakukan dengan menghitung kapasitas dukung fondasi tiang pancang tunggal setiap kedalaman dengan interval kepercayaan $60 \%, 80 \%$, dan $95 \%$ setiap cluster terlebih dahulu. Hasil nilai kapasitas dukung ultimit fondasi tiang pancang setiap kedalaman dengan tingkat kepercayaan, kemudian diplotkan untuk dibuat grafik hubungan kapasitas dukung fondasi tiang pancang $\left(\mathrm{Q}_{\mathrm{u}}\right)$ dengan kedalaman (z) setiap cluster. Tiang pancang yang digunakan pada penelitian diasumsikan berbentuk lingkaran dan memiliki diameter bervariasi yaitu $30 \mathrm{~cm}, 40 \mathrm{~cm}$, dan $50 \mathrm{~cm}$. 


\section{$\mathbf{Q}_{\mathbf{u}}(\mathbf{k N})$}

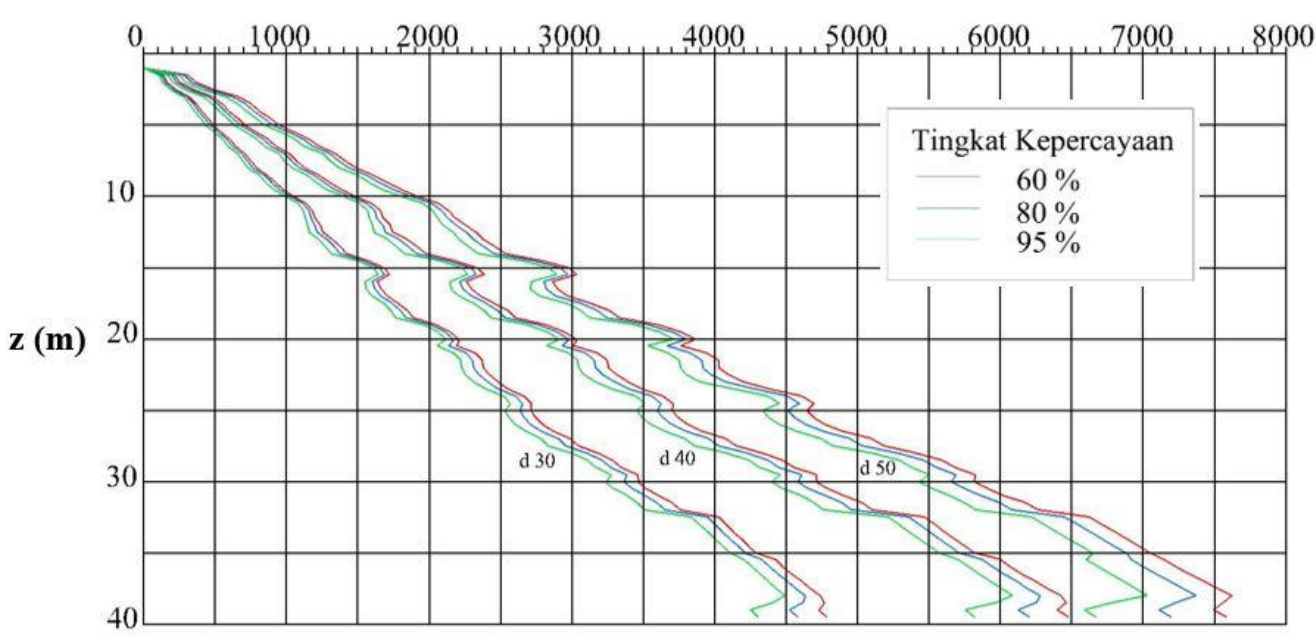

Gambar 3. Grafik hubungan kapasitas dukung ultimit tiang $\left(\mathrm{Q}_{\mathrm{u}}\right)$ dengan kedalaman $(\mathrm{z})$ pada cluster lempung keras

$\mathbf{Q}_{\mathrm{u}}(\mathbf{k N})$

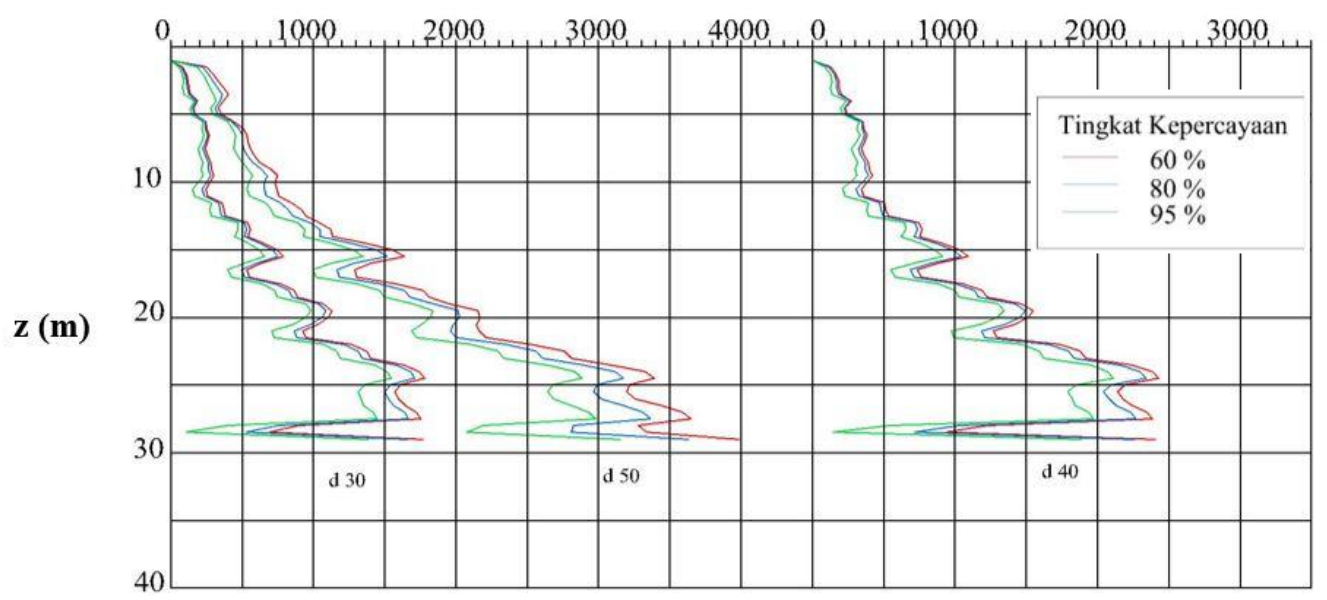

Gambar 4. Grafik hubungan kapasitas dukung ultimit tiang $\left(\mathrm{Q}_{\mathrm{u}}\right)$ dengan kedalaman $(\mathrm{z})$ pada cluster lempung sangat kaku

\section{Studi Kasus}

Studi kasus ini digunakan untuk menyelidiki hasil penelitian dengan cara membandingkan analisis metode clustering dan metode konvensional cara Meyerhof. Untuk studi kasus, diambil tiga sampel titik uji SPT diluar dari data yang dianalisis tersebar di Kota Surakarta, seperti terlihat pada Gambar 5.

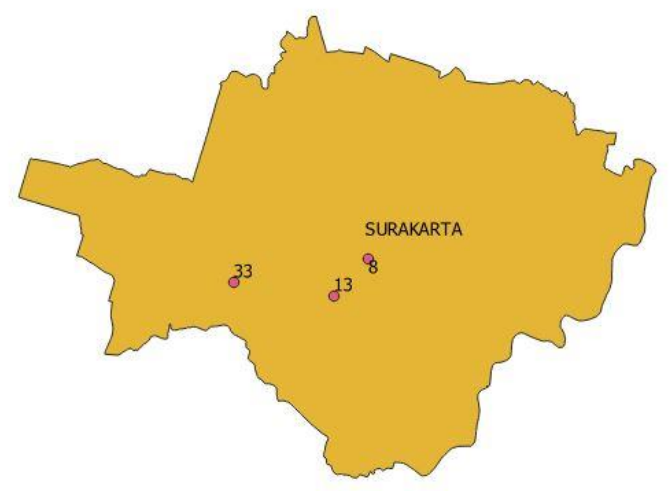

Gambar 5. Titik lokasi data SPT untuk studi kasus 
Tabel 2. Rekapitulasi studi kasus

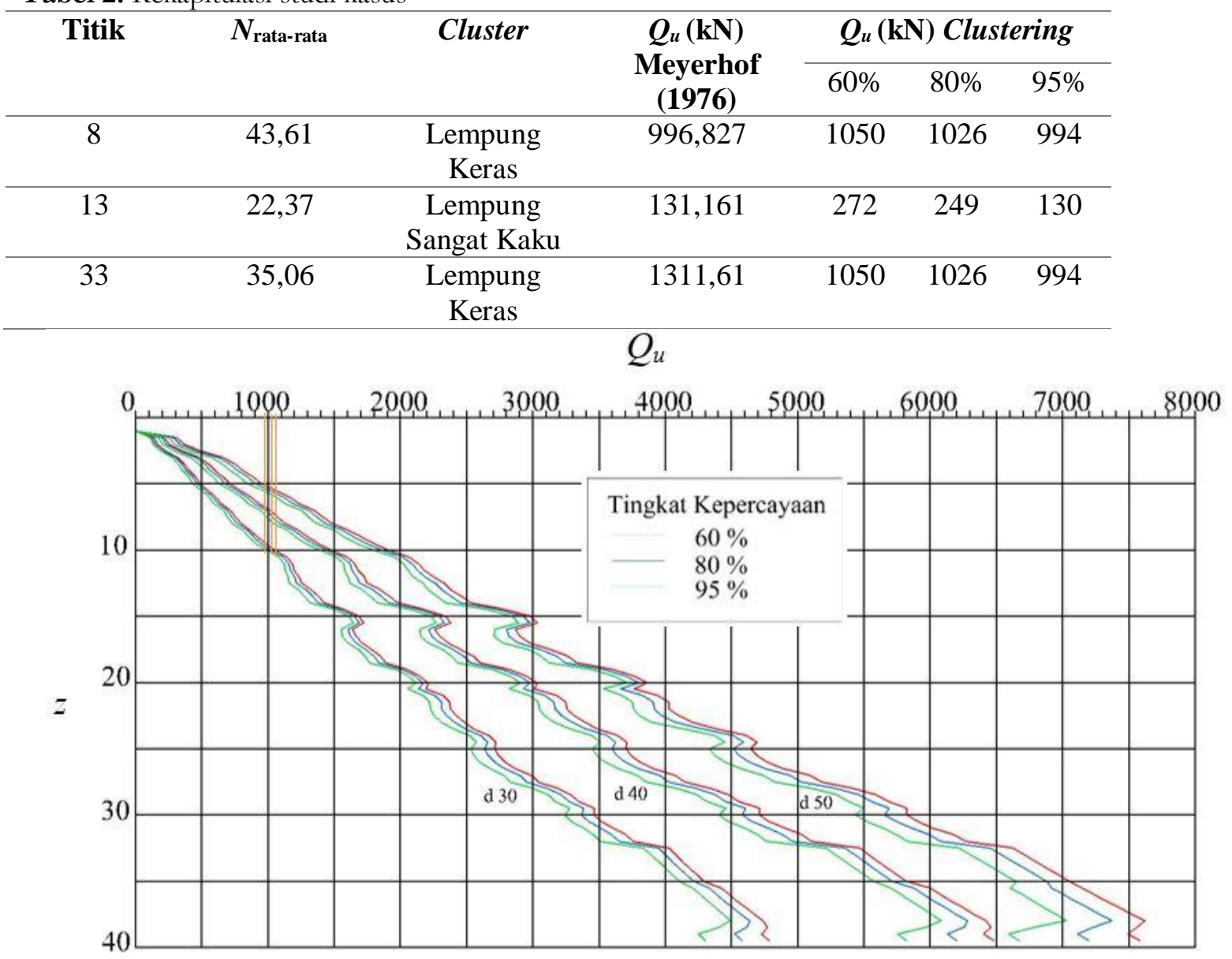

Gambar 6. Grafik cluster lempung sangat kaku untuk studi kasus

\section{KESIMPULAN DAN SARAN}

\section{Kesimpulan}

Berdasarkan hasil pehitungan untuk mendapat nilai kapasitas daya dukung fondasi tiang tunggal menggunakan metode clustering diperoleh kesimpulan Kota Surakarta dominan memiliki jenis tanah lempung sangat kaku dan tanah lempung keras. Hasil grafik hubungan kedalaman $(z)$ dan kapasitas dukung fondasi tiang pancang tunggal $\left(\mathrm{Q}_{\mathrm{u}}\right)$ dengan interval kepercayaan menunjukkan bahwa:

- interval kepercayaan semakin besar menghasilkan kapasitas dukung fondasi tiang pancang tunggal $\left(\mathrm{Q}_{\mathrm{u}}\right)$ semakin kecil. Jika diambil diameter $30 \mathrm{~cm}$ kedalaman 10 meter cluster lempung sangat kaku, maka hasil pembacaan grafik menunjukkan nilai $\mathrm{Q}_{\mathrm{u}}$ interval kepercayaan $60 \%=1050 \mathrm{kN}, 80 \%=1026 \mathrm{kN}$, dan $95 \%=994 \mathrm{kN}$.

- Lapisan tanah yang semakin keras diperlukan kapasitas dukung ultimit yang lebih besar. Hal ini ditunjukkan oleh nilai $\mathrm{Q}_{\mathrm{u}}$ cluster lempung sangat kaku lebih kecil daripada cluster lempung keras jika diambil diameter $30 \mathrm{~cm}$ dan kedalaman $10 \mathrm{~m}$ dengan interval kepercayaan $60 \%$ diperoleh nilai $\mathrm{Q}_{\mathrm{u}}$ sebesar $520 \mathrm{kN}$ pada cluster lempung sangat kaku dan nilai $\mathrm{Q}_{\mathrm{u}}$ sebesar $1050 \mathrm{kN}$ pada cluster lempung keras.

Hasil studi kasus membandingkan metode clustering dengan metode konvensional Meyerhof (1976) menunjukkan bahwa metode dapat digunakan sebagai rekomendasi dalam memprediksi kapasitas dukung fondasi tiang pancang tunggal $\left(\mathrm{Q}_{\mathrm{u}}\right)$.

\section{Saran}

1. Perlunya data SPT lain di wilayah yang belum merata persebaran datanya.

2. Perlunya penelitian dengan metode clustering lain untuk mengatasi persebaran data yang tidak merata.

3. Mempersempit wilayah saat melakukan intepolasi.

4. Untuk perhitungan penelitian selanjutnya dapat mencoba menggunakan bantuan pemrograman komputer. 


\section{UCAPAN TERIMAKASIH}

Allah SWT yang telah memberikan banyak nikmat-Nya sehingga penelitian ini dapat terselesaikan, orang tua tercinta yang selalu memberikan dukungan tiada henti, Bapak R.Harya Dananjaya H I,S.T.,M.T, Ibu Ir.Noegroho Djarwanti,M.T. yang telah banyak membimbing dan memberikan arahan dalam penulisan penelitian ini, serta teman-teman sipil seperjuangan.

\section{REFERENSI}

Alfredo H-S Ang, W. H. (1975). Konsep-konsep Probabilitas dalam Perencanaan dan Perancangan Rekayasa Prinsip-prinsip Dasar Jilid 1. Jakarta: Erlangga.

Arganata, O. F. (2015). Korelasi Daya Dukung Pondasi Tiang Bor Dengan Metode Reese anda O'neill terhadap Metode Terzaghi and Peck Berdasarkan Hasil Uji SPT. Jurusan Teknik Sipil, Universitas Sebelas Maret .

Bowlesh, J. E. (1998). Analisis dan Desain Pondasi Jilid 2. Jakarta: Penerbit Erlangga.

Bowlesh, J. E. (1997). Analisa dan Desain Pondasi, Edisi keempat Jilid 1. Jakarta: Erlangga.

Das, B. M. (1994). Mekanika Tanah (Prinsip-prinsip Rekayasa Geoteknik). Jakarta: Erlangga.

Das, B. M. (2006). Principles Of Geotechnical Engineering. US: The University of Texas.

Gultom, E. B. (2010). Analisi Daya Dukung Pondasi Tiang Pancang Tunggal pada Proyek Pembangunan PLTU 2 Sumatera Utara 2x200 MW Pangkalan Susu-Sumatera Utara. Jurusan Teknik Sipil Universitas Sumatera Utara .

Hardiyatmo, H. C. (2010). Mekanika Tanah 1. Gadjah Mada University Press.

Hardiyatmo, H. C. (2002). Teknik Pondasi 1. Fakultas Teknik Universitas Gajah Mada.

Hardiyatmo, H. C. (2008). Teknik Pondasi 2. Fakultas Teknik Universitas Gajah Mada.

Maharani, G. (2015). Komparasi Nilai Daya Dukung Tiang Tunggal Pondasi Bor Menggunakan Data SPT, Hasil PDA Test, dan Hasil Loading Test pada Tanah Granuler. Jurusan Teknik Sipil, Universitas Sebelas Maret . 